\title{
GCU
}

Glasgow Caledonian

University

University for the Common Good

\section{From anger to solidarity: the emotional echo-chamber of Gezi Park protests}

Eslen-Ziya, Hande; McGarry, Aidan; Jensen, Olu ; Erhart, Itir; Korkut, Umut

Published in:

Emotion, Space and Society

DOI:

10.1016/j.emospa.2019.100632

Publication date:

2019

Document Version

Author accepted manuscript

Link to publication in ResearchOnline

Citation for published version (Harvard):

Eslen-Ziya, H, McGarry, A, Jensen, O, Erhart, I \& Korkut, U 2019, 'From anger to solidarity: the emotional echochamber of Gezi Park protests', Emotion, Space and Society, vol. 33, 100632.

https://doi.org/10.1016/j.emospa.2019.100632

\section{General rights}

Copyright and moral rights for the publications made accessible in the public portal are retained by the authors and/or other copyright owners and it is a condition of accessing publications that users recognise and abide by the legal requirements associated with these rights.

Take down policy

If you believe that this document breaches copyright please view our takedown policy at https://edshare.gcu.ac.uk/id/eprint/5179 for details of how to contact us. 
From anger to solidarity:

The emotional echo-chamber of Gezi Park Protests

Author 1 Dr. Hande Eslen-Ziya, Stavanger University, Norway.

Author 2 Dr. Aidan McGarry, Loughborough University, London, UK

Author 3 Dr. Olu Jenzen, University of Brighton, UK.

Author 4 Dr. Itir Erhart, Bilgi University, Istanbul, Turkey.

Author 5 Prof. Umut Korkut, Glasgow Caledonian University, UK

By using the Gezi Park protests that took place in Turkey in 2013 as a case, we explore the significance of emotional echo-chamber involved in protests. The analyses are composed of thirty-seven interviews conducted with activists on how they define and understand their preferences and motivations for protesting. We discuss how participants get influenced by beliefs, motives and opinions and bring forth the changes of emotions during such processes and help create an emotional echo-chamber.

Key words: Protest movement, social movements, emotions, emotional-echo chambers, anger, solidarity, hope.

Correspondence Address:

Dr. Hande Eslen-Ziya, Associate Professor, Department of Media and Social Sciences, University of Stavanger, Norway. hande.eslen-ziya@uis.no *corresponding author* Dr. Aidan McGarry, Reader in International Politics, Institute for Diplomacy and International Governance, Loughborough University, London, Here East, Queen Elizabeth Park, UK. E15 2GZ. a.mcgarry@lboro.ac.uk Dr. Olu Jenzen, Principal Lecturer in Media Studies, School of Media, University of Brighton, UK. o.jenzen@brighton.ac.uk Dr. Itir Erhart, Associate Professor, Department of Media and Communication Systems, Bilgi University, Istanbul. Turkey. itir.erhart@bilgi.edu.tr Prof. Umut Korkut, Professor in International Politics at Glasgow School for Business and Society at Glasgow Caledonian University. umut.korkut@gcu.ac.uk 
From anger to solidarity:

The emotional echo-chamber of Gezi Park Protests

\section{Introduction}

Social movements act as both a transporter of meaning and organizer of protests where emotions can be channelled towards a specific target or outcome. There is an emotional component to how people come together and take part in social movements. As Jasper (1997, p. 127) argues it is emotions which "give ideas, ideologies, identities and even interests their power to motivate." In return, through social movements, such emotions become transferred into and augment collective claims. Despite such a strong link, the politics of protest and the

role of emotion involved in social movement mobilization were dismissed in the study of social movements and political protest by models of rational action (see Goodwin, Jasper and Polletta 2001a; Jasper 1998). Only recently social movements research (Von Scheve, 2017; Castells, 2015; Woods, Anderson, Guilbert, and Watkin 2012) focused on the emotional displays and strategies used by the protestors and their involvement in protest activities.

This article by examining the Gezi Park protests that took place in Turkey in 2013, will be novel in the approach it explores the significance of emotional echo-chambers that serve as a glue for bringing and keeping different groups of people together in protests. Emotional-echo chambers reverberate from the concept echo-chambers existing within the social media where "one is exposed only to opinions that agree with their own" (Garimella et al. 2018). Garimella et al. (2018: 1) approach the concept of echo-chambers under two components: "the opinion that is shared by the user, and the 'chamber', i.e. the digital network around the user, which allows the opinion to 'echo' back to the user as it is also 
shared by others." Similarly, what we coined as emotional-echo chamber gets created through the emotions (and not opinions) that is shared by the protestors, and the 'chamber', i.e. the social environment around the participant (not the digital network), which allows the emotion to 'echo' back to the protestor as it is also shared by others. We specifically study the emotional-echo chamber created by ideologically different groups of people gathering together and protesting during the Gezi Park protests, structuring (giving meaning to their emotions) and sharing and echoing such emotions among other protesters in the park. As we will show, the echoing of emotions during the Gezi Park protests have reached what we call a chamber (the social network around the protestor) that may not have been possible (because of their politically and ideologically diverse background) if they were not together in the park. We will argue, the social network created by being in the park not only allows the emotions to echo to others but also through such echo's brings back such emotions to its producer. This echoing helps emotions to travel within the park and help strengthen one's existing emotions. How this reverberate in our case will be explained further in the paper.

Our analyses are grounded on of thirty-seven interviews conducted with activists on how they define and understand their preferences and motivations for protesting. Our goal is to unpack the emotional trajectories of activists and their involvement and ask, "how emotions are transformed into action." Castells (2015: 4). For this, we are interested in studying how participants are influenced by beliefs, motives and opinions and will bring forth the changes of emotions during such process. By employing social constructionist approaches to emotions, we will discuss how protestors build solidarity across different boundaries and create a collective Gezi identity, known as 'Gezi Spirit'. For this we will talk about three socialization processes: (1) views drawing on the emotional template of 'Gezi Spirit'; (2) belonging - forming intense affective ties within the social movement in action; and (3) reconciliation-staging expressive public rituals of reconciliation between groups that 
previously had opposite interests and help create an emotional echo-chamber. We argue that emotions exist in every stage of political protest, but transform as the protest evolves and continues, and during this process it is the emotional-echo chambers that serve as a glue to bringing and keeping very different groups of people together. We will show (and illustrate in Figure 1), different participants with different politically and ideologically diverse backgrounds create an emotional-echo chamber within the Gezi Park, where collective emotion of anger is transformed into protest action. And once the emotional echo chamber is created, collective emotions became solidarity and hope.

\section{Emotions and protest}

How do we make sense of emotions in a socio-political context like the Gezi Park protest? How do emotions contribute to change and help transform these protestors? According to Jasper $(2011,1997)$ emotions are a significant facilitator behind why individuals join, stay and later abandon social movements.

The social movement scholars (like Goodwin 1997; Goodwin, Jasper, and Polletta 2001; Gould 2009; Jasper 1998) discuss how emotions in social movement and protest events play a significant role either by facilitating or hindering protest movement. Though earlier scholars ignored the important role emotions, more recent scholars explicitly theorize emotions and their role in protest participation. By studying the relationship between emotions and social protest will argue that, in order to understand the reasons why people participate in protests one must understand emotions, what these emotions are and how they lead to protest behaviour. In doing so, we will take Massumi’s (2002) approach when talking about emotions in protest (and not affect). We will use emotion as individualised and socialised part of affect where it is reflected in conventional expressions of both act and 
language. While emotion bares a rational and conscious constituent, affect carries the opposite components, it is non-rational and non-conscious. As the interviews in this study are based on individual reflections of past events and because they include a certain introspection and thinking back, we decided to name such sentiments associated with the past protests as emotions. We are fully aware that it is difficult to separate between the two as they are tightly interwoven.

In all stages of protest (getting involved, participation, staying or dropping out from the protest) emotions play a major role. They are, "implicit in the mobilization, framing and organization of social movements" (Woods et al. 2012: 570). Goodwin, Jasper and Poletta (2000; 2001) sees emotions as being socially constructed. In other words, contextual factors play an important role in the perception of events where such interpretation in return shapes the very emotions protestors feel. According to Goodwin, Jasper and Poletta (2000 and 2001) emotions play a major role in starting social movements. Because emotions are influenced by contextual factors and they are situation specific, they can also be manipulated easily. It is not difficult to imagine that activists, in order to raise awareness and attract more supporters, use anger to galvanise the masses. In fact, anger is defined as the prototypical protest emotion (see Jasper, 1997; 1998; Kim 2002).

Negative emotions such as anger, resentment, and frustration (Koçan and Öncü 2015; Gamson 1992) as well as positive ones such as pride, joy, and hope (Costa, Rotabi, Murnane and Choudhury 2015) have been identified as the most common sentiments associated with protests. Emotions are not individual responses to external events, but they are also political and can act as a powerful source either to preserve a status-quo or to de-stabilize and change it. Within social movement studies there is a focus on what type of and how certain emotions are activated to foster change. For instance, Jasper and Poulsen (1995) talk about unexpected events causing "moral shocks", by which they mean mental disruptions leading to anger and 
motivating people to participate in social movements. Here, by focusing on the emotional trajectories of protest and the factors motivating individuals to join and stay we aim to demonstrate when, how and which emotions are expressed by individuals taking part in the Gezi Park protest. We will further demonstrate that, emotions exist in every stage of political protest, acting as glue to build solidarity and belonging due to the emotional echo-chambers created in these protests.

\section{Method}

Data Collection and Analysis

Thirty-seven participants who took active part in the Gezi Park protests were included in the study using a snowball technique. The semi-structured in-depth interviews were conducted in Istanbul and in UK (spring 2017) in Turkish and then translated into English. Interviews focused on themes such as; why and when the interviewees took part in the protest, what triggered their participation, how they felt during the protests, how (through what channels) and which emotions did they express and what kept them going in protests and so on. The respondents reflect many different types of protesters both men and women, from the ages of mid 20s to mid 70s. They were all activists during the Gezi Park protests, some camped in the park some came on daily bases, some opened their homes, shops, cafes and restaurants to protect protestors from the police violence and others were there out of curiosity and interest or to create change. While some of the protestors were affiliated with and represented nongovernmental organizations (NGOs), others were students. All the names used in this article are pseudonyms.

The computer software package Nvivo was used to systematically code and analyse the raw data and to develop and integrate the emerging analytic categories and themes. The 
first stage of open coding was used to generate descriptive and summative codes for the interviews. These codes related to questions such as, why participants took part in the protests (i.e. reasons for participation) or how they felt during the protests (i.e. the different types of emotions felt). Later, more specific attributes were coded. For instance, the emotion category had sub components like anger, frustration and joy. The project team sought to reach consensus during the process of coding and developed a common code book. The researchers evaluated the appropriateness of the coded segments of the data and aimed to reach consensus. The team decided on the most salient categories in relation to emotions, which later form the basis for the organization of our results. Memos helped interpret both what was obvious in the text and the subtext or what was not so obvious / hidden and served to guide the 'naming' of categories.

\section{Understanding Gezi Protests through Emotions}

The Gezi Park protests that took place in Istanbul Turkey between 27th of May and 30th June 2013, started as a sit-in by environmental activists as a reaction to the government's plans to convert Gezi Park into a mall modelled after the Ottoman janissary barracks. The Gezi Park protest became the most significant political uprising in recent Turkish history and holds a unique position within Turkish politics through bringing together politically, culturally and socially diverse groups including feminists, environmentalists, factory workers and leftists, soccer fan groups, LGBTI activists, post-materialist youth, observant Muslims, ethnic and religious minorities (from the Kurds and Roma to Alevis and non-Muslims), middle-class secularists as well as ultra-nationalists (ulusalcılar). The protests birthed a new ideology 
called 'Gezi Spirit'(Akcali, 2018) and new identity called 'Çapulcu', Both this new ideology and the 'Çapulcu' identity, we argue, was created due to the emotional processes involved during the building of collective community and solidarity.

The protestors that joined forces and resisted together were confronted by police using tear gas, rubber bullets, and water cannons against them (Eslen-Ziya and Erhart 2015 and Atak, 2013). Rapidly, it turned into a unification of all groups who were against the authoritarian and patriarchal policies of the ruling AKP (Justice and Development Party) government and the Prime Minister at the time, Recep Tayyip Erdoğan (now President). The movement continued with neighbourhood forums (also called 'people's assemblies') where people gathered together in parks in cities like İstanbul, İzmir, Eskişehir to discuss various social issues that differed vastly; ranging from environmental concerns, women's rights, LGBTI rights, animal rights, freedom of expression to unequal distribution of wealth (Navaro-Yashin 2013; Farro and Demirhisar 2014).

As we show in Figure 1, the emotions involved during the Gezi Park protest gave rise to collective 'Çapulcu' identity, and the notions of solidarity and unity. Once the collective identity was established, the Gezi Park protest became more meaningful for the protestors. Bernstein (1997) discusses the importance and the use of collective identity during the Lesbian and Gay Movement in the US, and how it gives rise to a shared identity during the protests. We argue that, the emotional processes involved also contributes to such collective identity development. In our case, being identified as 'Çapulcu' served as the beginning for the formation of the emotional echo-chambers. According to Collins (2004) for instance, once such shared identities are created, rituals play a major role in helping protestors to mobilize. According to Van Ness and Summers-Effler (2018: 415) such rituals generate

\footnotetext{
1 Çapulcu, is a Turkish word for "looter", and was first used by Erdoğan to define the protestors and later was adopted by the protestors. The protestors also called Gezi Park Çapulcuistan (the land of the Çapulcu) and the live-stream online channel that they founded as a reaction to the mainstream media, the Chapul TV.
} 
"feelings of collective effervescence, which creates group solidarity, individual emotional energy, symbols of group membership, and standards of morality...[and] members imbue these symbols with a sense of righteousness and morality, passionately defending them against impropriety and violations." In our case rituals like cleaning the park or praying served as a social glue of the movement, and helped maintain the echo-chambers by enabling the shared mood and emotions to echo within the created chamber. This in return strengthened the barriers to outsiders making it impossible for other types of emotions (such as: fear, hate) to enter the park and break the established solidarity.

Emotions were salient for not only making people mobilise but also making them stay and attribute meaning to their existence within the park. As argued by Koçan and Öncü (2014: 184) the Gezi Park protests "corresponded to such an exceptional episode of densely experienced emotions in the lives of a large number of individuals in Turkey". Inside, the park was transformed into a "utopian pluralist space" (Eslen-Ziya and Erhart 2015: 474) as an egalitarian and all-inclusive milieu that brought people together regardless of their differences. Erhart (2014) shows how very diverse groups, such as rival football teams' fans from Galatasaray, Fenerbahçe and Beşiktaş, formed a new identity under the name 'Istanbul United' and demonstrated against the government during the Gezi Park protests. Within the park, protestors engaged in creative and performative actions guided by both positive (solidarity, pride) and negative emotions (anger, frustration). These emotions in fact helped being and belonging to the Çapulcu collective.

As the rituals in the park such as building a library, doing yoga or praying, cleaning, eating, gardening, talking (McGarry, Jenzen, Eslen-Ziya, Erhart and Korkut 2019) as well as protesting against police violence all constitute experiencing of these emotions intensely with a potential to galvanise others to participate. Emotions then, not only enabled one to take part in protest but through the echoing of such emotions within the park allowed for protestor 
communication. Such emotions were echoed through creative and performative action, social media (Twitter and Facebook posts) and with direct encounters with police forces. Later, we will discuss the emotional template of the Gezi Park protest by explaining the emotional trajectories of protest and the factors motivating individuals to join and stay in the protest by asking: Did the emotions change once the Gezi Park protests started; did people start for a similar reason and stayed for another?

\section{Emotional Template of Gezi Spirit}

When it comes to motivations for participation both negative and positive emotions were found to play a major role. It was almost always the negative emotions, particularly anger, that triggered protest participation. Anger was found to "locate blame for injustice" and more than other emotions motivate punitive and/or preventative demands against the unjust treatment of others (Henderson 2008: 30). Our analyses also showed a transformation of emotions: anger turning into more positive emotions. As our participants took part in the protest, anger was converted into hope and feelings of belonging. Once they were protesting, they said, they experienced like belonging to a cause, to a group, to the 'Çapulcu' identity. Yet, anger was never fully erased and from time to time participants felt both frustrated and angry towards the government or the police violence against protestors. In this section, in light of our interviews, we will argue that it was not the negative feelings per se but the transformation of those feeling into more positive ones that kept our participants at Gezi Park protests, sustaining their protest actions. First, we will discuss the roles of negative and positive emotions in protest participation, later we will turn to solidarity, feelings of belonging, hope and re-conciliation between groups that previously had opposite interests as 
significant facilitators for turning negative emotions into positive ones. We will also discuss the creation of emotional echo-chambers during this process.

\section{Shared anger and frustration}

In the interviews, one of the major themes was anger. The protestors maintained they felt angry before taking part in the protests. It was the building up of anger that made them join others in the park. The threat of the cutting down the trees in the Gezi Park, was the straw that broke the camel's back that triggered protest action. One participant emphasized how the feelings of injustice and restlessness later turned into anger. "They don't have the right to do this", or “it is unfair" was Onat's very words:

First, the damage caused to environment... this made me very angry and I thought that they don't have the right for this. Second, government took away the freedom of expression from people, attacked people as if attacking an enemy, those gas bombs, nightsticks, all those arrests, and I thought that they don't have the right to do all these. It was unfair. Therefore, I decided to take side with the people (Beyza).

The feeling of being treated unjustly or unfairly, according to Cass and Walker (2009), is a significant emotional dimension that results in activism and protest and this was evident in both Onat's and Beyza's statements. While one reason for prompting choices for participation might be as Gould (1993) describes, the desire to achieve "fairness" others might be due to the anger, resentment and bitterness governments generate via disappearances, assassinations of civilians, or a lying like Nepstad and Smith's (2001) 
describe. The state of emotion that caused masses to protest at the Gezi Park protests was anger.

The state of anger continued during the protests and still manifested itself during the interviews - long after the protests ended. Koçan and Öncü (2014: 180) argues that Gezi protestors were undergoing "a moral shock or outrage". Our interviews also showed that, anger was due to a combination of factors. The intervention to the environment and park (Onat and Beyza) was one of them:

It was the intervention to the park that made me angry. For me, the starting point and the main issue was their demand to transform Gezi Park from a park into a construction site (Onat).

In the evening of 31st of May, I got very angry when I was looking at the tweets and "ekşi sözlük" (a local online dictionary and social media site) on my computer. I realized that some things and events were happening. When I saw people passing near my window in the evening, I said something is happening...I didn't sleep that night. And I got ready and went out early in the morning (Beyza).

For many others, the authoritarian government, its restrictive policies, the intervention to their social lives and the attacks made to the founders of the Republic (by Erdoğan) and “Erdoğan's personality" per se were further reasons that triggered negative emotions.

As I don't like anything Tayyip does... And especially because he was going to build a mosque inside Gezi Park as well as a barrack... all these put me in action (Handan). 
This was a protest against Erdoğan. It was something against the (daily) life restrictions performed, let's say, by the secular or more civil part of the society. (Hasan).

Hence anger, discomfort and negative emotions were there, but especially with the brutal and unfair treatment of police towards peaceful demonstrators, such emotions strengthened. Once the anger was triggered by the Gezi Park protests the participants decided to take an active role in the protests. As it is reflected in Figure 1, in fact, for most of them, the cause of such anger (restrictive policies, intervention to social lives) was the very reason that made them come to the park in the first place, but what kept them there and protesting was due other set of emotions created with the events taking part in the protest:

There is construction all around the city, and I know it is not possible not to cut trees... what we are saying is they should plant as much as they cut, but this was not the reason [why I stayed in the protests]. I could not accept their [governments and the police forces'] treatment against the protestors. I was there because of this (Erol).

It was the intervention to the park that made me angry...However, afterwards, this event has changed a dimension especially with the interventions of the government... and this time, because of accumulated pressure on people and being outcast -and here were people from all strata- it turned into such an incredible unexpected big protest (Onat). 


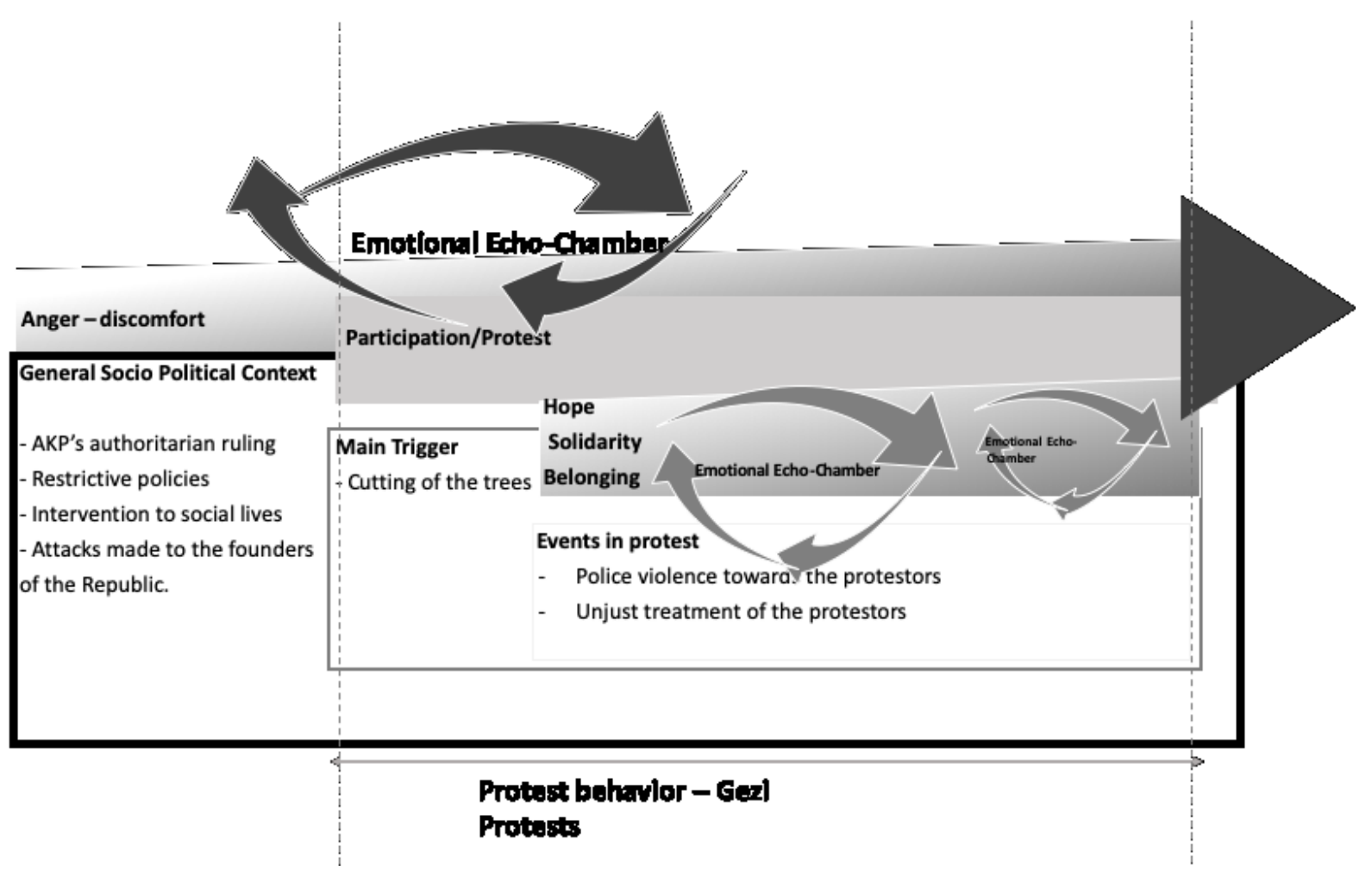

Figure 1 The emotional echo-chamber of Gezi Park Protests

As seen in the above quotes and illustrated in Figure 1, anger has initiated the pathway to protest. Therefore, the inclination to take part in the protests dependent on how such anger was reinforced by the current events. Sometimes the negative emotions were strengthened through the information shared on social media. In such platforms, negative emotion evoking images and texts of the protests were circulated. The images like the iconic women in red - representing defenceless protestors and the unjust treatment of the police - or texts and personal stories of police violence, and brutality fostered anger and impacted the participation in the protest itself. Similarly, Ömer describes how he was touched during the protests emotionally and wanted to influence others. In order to gather attention to the protest, he shared a video with a note saying he will be there at the park:

There was a video on social media. This [talking about the image of an old woman talking with the police forces] touched me so much! She was addressing the people 
like this "my child, this is the only green place that we can go and breathe, and they are going to destroy this place and build a shopping mall”. After I saw that, I shared it and I wrote "after work at 18.00, I am going there, too! It triggered my emotions (Ömer).

Ömer deliberately shared a video that would evoke emotions and motivate others to take a part in the protest. This, shows how protestors work on emotional displays and use strategies to create protest participation and involvement (Von Scheve, 2017; Castells, 2015). In such instances, social media was used as a tool to inform others of the protest, and this was done by sharing images that provoked emotion:

I used social media was to make people alert! [It was] for people who were unaware of the protest and didn't know what was happening... we were saying, I am here, and you should know! Instead of calling and saying, 'come here', you can actually make yourself be understood better with a single photo or video (Bora).

For others the negative emotions were strengthened through one-to-one experiences of repressive treatment of protestors by the police. One of the participants Bora, who took pictures of such disproportionate use of power by the police, distributed these images across social media. He said these were things that touched him emotionally that he felt obliged to share and influence:

There isn't a single person who joined the protest and did not get affected by the events in the photograph that I am showing you [a photograph displaying police using tear gas on the protestors] (Bora). 
He also talked, how such a photo can create and provoke emotions as if one was there. He saw the influential power of social media for sharing information and influencing others. These images evoked anger and inclined viewers to take active role as protestors:

Because it tells about the whole process within a single frame [talking about a photograph displaying police using tear gas on the protestors] ...people who otherwise will never get involved in such events, like me, found themselves all of a sudden in the streets. Because these images made you angry, as if you were there! (Bora).

Bora says, the protest itself was symbolic way of saying enough is enough! Similar to Koçan and Öncü's (2014: 180) findings, our participants too felt "obligated to join the mobilization to restore fairness and justice". And once they did take part in the process, they started feeling good about it. As illustrated in Figure 1, negative emotions like anger turned into a positive one.

Seeing that our power is strong enough, and that we can protect things which we believe are important...we can make a difference... felt good (Melis).

Like Melis, by taking part in the protest, they felt that they can make a difference. The notion of having control brought hope for their future and turned negative emotions (anger) into positive ones (feelings of belonging).

As reflected in the interviews, emotions can be identified as feelings and dispositions protestors have in relation to a specific object. Yang (2000) who studies the Chinese Student 
Movement argues that negative emotions like anger, outrage, shame and fear were stimulated by interactions with opponents, while positive emotions like joy, compassion and pride were stimulated through interaction with other activists inside the movement. Jasper $(2011,1998)$ also asserts that, emotions of protest separate between different objects of emotion like the opponent, or the in-group. Similarly, in the Gezi protests too when these feelings were towards the opponent -Turkish government, the police or Erdoğan - it caused anger while when these feelings were towards the in-group, it created positive emotions like belonging. According to Nepstad (2004: 139) when activists have an identifiable target to blame, feelings of solidarity and unity can grow. In our case too, the protestors by blaming the government, the police or Erdoğan were able to unify their attention transform their negative emotion anger and hate into belonging and unity. Though anger was altered and transferred into a positive emotion, it never totally disappeared. The anger towards the government, the police or Erdoğan was still there. Such trajectories of emotions enabled emotions to transform anger into positive emotions like joy, hope and/or solidarity. In the next section, we will discuss the emotion that anger transformed into within the Gezi Park: belonging.

\section{Belonging - forming intense and affective ties within the Gezi movement}

Protests have a transforming power, strengthening emotional bonds between fellow protestors and founding collective identities (Van Troost, Van Stekelenburg and Klandermans 2013; Cayli 2017) Collective identities within social movements are established by solidarity, feelings of belonging together. This was also evident in our interviews. The Gezi experience created feeling of belonging and togetherness, by uniting differences, and forming 'wee-ness' and solidarity: 
There was a great unity, and there was no discrimination based on race or religion...Everybody was there together (Handan).

There were good things; the solidarity and doing things together (Can).

The feeling of unity uttered and belonging, was what we defined elsewhere (McGarry, Jenzen, Eslen-Ziya, Erhart and Korkut 2019) as Gezi Spirit. Gezi Spirit emerged when the protesters felt that there were also others sharing similar experiences and feelings and that they were not alone. This was around the time when the collective Gezi identity started to form. It was formed through the protests against the police force and social activities. Sharing food, cleaning the park, creating a library and organizing yoga or praying together were all participatory activities that enabled one to one contact and strengthened the Gezi Spirit.

I don't want to romanticize, but when I saw those people [referring to the people at Gezi park], our eyes filled with tears. Because we have always been alone...(Berk)

First, people who were feeling lonely and unaware of each other said 'actually I am not alone'. I think this was very valuable. We all reached that dead end; 'I am thinking this, but I am alone'. No, you weren't alone! (Bora).

As the above quotes demonstrate and we argue elsewhere (McGarry, Jenzen, Eslen-Ziya, Erhart and Korkut 2019: 298) "Gezi Spirit is performed through everyday activities as the protestors attempt to transcend their social heterogeneity and traditional ethno-nationalist, gendered and religious cleavages". The feeling of not being alone and acknowledging the 
presence of others with similarities despite their differences was an awakening moment for many of the participants. Being together and coalescing into one large Çapulcu community brought forth further positive emotions like feeling proud and having hope for the future. Hope became the major positive outcome of being part of a collective as well as inclusive Çapulcu identity.

Yes, I saw it on social media [referring to the image of protestors filling the Taksim square], it made me feel so enthusiastic to see such a crowd...such a proud moment. This is us! Oh my God, we are here! This is something that belongs to us! (Bircan)

Such transformative power of emotions demonstrated itself as emotional solidarity and hope and worked by way of an agency widening participation among protestors. Hence, this section was an attempt to illustrate how the shared rituals and emotions (as displayed in Figure 1) by further facilitating emotional echo-chambers enabled the shared mood and emotions to echo within the created chamber. This in return, by strengthening the barriers to outsiders making it difficult for other types of emotions (such as: fear, hate) to enter the park. Once the emotional echo-chambers were formed, it was harder for outside emotions to enter or forces to break the established solidarity.

The utopic space created in the park, and the emotional echo-chamber helped reconciliation among groups that previously had opposite views and interests and kept them going. Henceforward, resulting in more than 2.5 million people, with different worldviews and ideologies, protesting (Y1lmaz and Y1lmaz 2015). Eslen-Ziya and Erhart (2015: 474) defines such space as "utopic" because it was "gender sensitive and all inclusive, and which enabled the expression of a postheroic leadership." For them, postheroic leadership was "non-hierarchical and democratic alternatives to leadership" (Eslen-Ziya and Erhart 2015: 
472). Here we will further argue that, such non-hierarchical and democratic nature of the protests with no appointed leader, where everyone was equal despite their ideological differences and their previous polarizations was made possible through the emotional echochamber that was created. Shared anger and frustration and emphasis on solidarity and unity (while making differences less important) enabled possible alliance and political mobilisation between ideologically very different groups. The emotional echo-chamber became the resource to fuel mobilisation efforts. In the following section, we will further discuss how reconsolidation between very different groups was mirrored in our participants' experiences.

\section{Re-consolidation between groups that previously had opposite interests and the role of} emotional echo-chambers

The juxtaposing of the Turkish flag and the Kurdish separatists' flag, or the image of a man hand in hand with a woman in headscarf while holding a picture of Atatürk ${ }^{2}$, exemplify the distinctive connection of very different communities within the park. However, such diverse and historically conflicting identity structure of Gezi protestors, was not embraced immediately. Our interviews showed that, as the protestors spent time together within this utopic space, feelings of dislike towards people they don't know, or ideologies they don't support lessened.

According to Keyman (2014: 29) since 2001, "every election AKP won resulted in increasing polarization in terms of secularism, ethnicity and religion...as Erdoğan and the AKP have become stronger, polarisation widened and deepened". During the period that led to Gezi Park protests, Erdoğan targeted groups that do not share his values and beliefs. He insulted Alevis, criticized the drinking behavior of students and pushed conservative gender

\footnotetext{
${ }^{2}$ Founder of Turkish Republic.
} 
norms by restricting women's choices. His desire to raise religious generation (dindar gençlik) was followed by his comments on women should have at least three children and that abortion should be banned (Burul and Eslen-Ziya 2018; Korkut and Eslen-Ziya 2016). The last decade clearly pointed a sharp polarization between AKP supporters and others. Keyman (2014) argues that from AKP's one electoral success to another there is a substantial rise in the polarization among citizens on topics related to secularism, religion and ethnicity.

However, long before the AKP government came to power Turkey was becoming acutely polarized. The conservative parts of the society were uncomfortable with the Kemalist reforms ${ }^{3}$. The comeback of the conservative Islamists started in the post 1980 military coup and continued when AKP came to power in 2002. Polarization among citizens was not just between the conservatives and the republicans, but also among nationalists and people from other ethnic or religious groups (especially Kurdish and Alevi citizens) as well as conservatives and LGBTI and / or women's groups. Hence while the common denominator for bringing people to the park was the AKP government and its restrictive policies, the protesters there, were also polarized among each other. However, as Halit states below, during the protests, unusual or unpredicted alliances were forged between groups that had divergent views on cultural, political and religious issues:

But flags with turquoise moon and stars, I did not even know what it meant politically, later I found out that they were nationalist group, a bit more extremist. I remember being curious when seeing groups like this. Thinking; who are these people, why are we in the same group with them? (Halit).

\footnotetext{
${ }^{3}$ After the secular Turkish Republic was founded in 1923 and Caliphate and Sultanate was abolished, religious sects were also banned, which caused major tension till this date among the conservative groups.
} 
Though, eventually our participants like Dilek started not caring being there with such diverse groups:

In spite of differences, it is possible to live together. I mean this is truly my first (experience) and that I was reactive first, to the PKK flag for instance, in the first days and then when I communicated with Kurdish people, I said 'so what!' (Dilek)

Our analyses further reveal that Gezi Park protests enabled protestors, like Dilek to see a common ground between very diverse and ideologically polarized groups. Correspondingly, Erhart reviews the unlike alliances formed during the Gezi Park protests (2014: 1729) and how feminist groups by organising a protest to condemn harassments towards women in headscarves united state feminists with the Islamist feminists:

This marked the beginning of the end of a long divide between the state feminists and the Islamist feminists who joined forces at the park against the common enemy: the oppressive and patriarchal state.

For our participants too, being in a space and observing unification of such diverse groups has had a transformative effect and the message conveyed was clear: 'together we stand, divided we fall' (Erhart 2014:1728).

A guy, who is doing the sign of the Grey Wolf ${ }^{4}$, is pulling away someone who is carrying a Kurdish flag... grey wolf and the peace sign were together! (Beril).

\footnotetext{
${ }^{4}$ The 'Bozkurtia' (Grey Wolves) are Turkish nationalist political symbol. The organisation has used the grey wolf as a figure of nationalist propaganda. The characteristic hand sign used by Grey Wolves represents a wolf head.
} 
This experience of Beril, is also expressed in Handan's words: "unity and solidarity!" Unity and solidarity were what the Gezi Park protests fundamentally meant for our participants. For Handan, like many other protestors, Gezi meant coming together from different walks of life, despite AKP's effort to create polarisation and division within the Turkish society. Erkan below, saw such experience as rewarding:

All these people with many differences were together and it was great! (Erkan).

The unification of such diversity was also commented on by the government officials like Nabi Avc1 - the Minister of Education of the time:

In five days, we achieved uniting contending social groups under a fog against us. Normally these fractions cannot come together, for it was something that the Parliamentary opposition has worked on for years. When the fog disperses, however, these contending identities will be shocked when they realise that they are sitting next to each other (translated by Damar 2016).

However, unlike what the government officials wanted, these contending identities continued being and fighting together in the same and for the same cause. The connection established by just being in the park, and the possibilities of uniting under a common cause despite the differences and past bitterness, were found to be the very reason that evoked positive emotions and the feelings of belongings. This was evident in the following quote: 
At this point, I think the most valuable thing that held people together... wasn't throwing stones at the police. The real thing was that this country's young people, elderly people.

The merging of antagonistic groups helped create a new social persona and a sense of belonging to the newly emerging Çapulcu collective identity and the formation of Gezi Spirit. Once a collective identity was formed, it served as the emotional echo-chamber. In this process emotions acted as a glue to build solidarity and the emotional echo-chamber worked to strengthen the existing emotions - and in some instances helped the emergence of new ones, like solidarity and hope. Similar to social media echo-chambers (Del Vicario et. al 2016), within the emotional echo-chamber activists act upon or are sensitive to certain emotions that confirm their emotional state. The activities inside an emotional echo-chamber are usually limited to only one type of content, hence making it difficult for dissimilar set of emotions to enter. During the Gezi Park protests, the echoing of emotions (like solidarity) enabled them to spread to diverse communities and permitted such emotions to reach a larger network. Similar to social media echo-chambers, emotions created within the emotional echo-chambers during the protests served as a catalyser for very different groups and united them. The emotional echo-chambers, by facilitating protestors for focusing on the shared emotions, freed them from their ideologies and worldviews that would otherwise polarise them.

Similar to how Breuer, Landman, and Farquhar (2015:594) would see social media as "transcended geographical and socio-economic disparities by providing a shared, mobilizing element", we see emotional echo-cambers serving similar means. Such shared element, in our case anger towards the authoritarian government or the hope for the future, became salient via the function of emotional echo-chambers. The diverse and historically contending 
identities become united under a common emotion (anger, solidarity and hope in our case) and a common enemy (Damar 2016). The emotional echo-chamber helped to connect protesters from various backgrounds of Turkish society. Once this diverse group shared a material space, they had the opportunity to interact and reflect on their common desires and criticisms and to help each other. As Berk said:

They attacked us with the morning ezan [call to prayer]. They circled us and there was tear gas everywhere. People were lying on the ground, we couldn't run anywhere. We carried some people who fainted, we tried to get them out...I was seeing only a gas cloud. I also fainted in this fog, somebody helped me to pass over the barriers as much as he could. (Berk).

Once, the emotional echo-chamber was created, and people started spending time together they started understanding and learning from each other. The following quotation is a very good example of such learning process about each other's experiences and the creation of one emotional echo-chamber:

People in Gezi learned that different people exist. Leftist people learned about LGBT. LGBT used to keep leftists at a distance, but those groups socialized. Socialists and ultra-nationalists socialized. Leftists had some kind of attitude against flags, it ended. In that sense, Gezi was pluralist and people learned empathy. (Ömer).

\section{Concluding Remarks}


In this article by focusing on trajectories of emotions, we demonstrated when, how and which emotions were expressed by individuals taking part in the Gezi Park protests. We showed that emotions exist in every stage of political protest, acting as glue to build solidarity and belonging among participants. By discussing the emotional trajectories involved during the period of protest we underlined the transformative side of emotions and emphasized that these emotions were not mutually exclusive, and anger and hope could work together within the same demonstration. Later we introduced the term emotional echo-chamber, that serves as a glue bringing very different groups together and creating solidarity.

This article was also an attempt to shed light on the role of emotion in activists' responses during the Gezi Park protests. Reactions to the government's plans to convert Gezi Park into a mall modelled after the Ottoman janissary barracks as well as the police brutality towards the protestors, as discussed by our interviewees, were highly emotional and triggered anger first. The transformative power of emotions within this social movement (Castells 2015) turned emotion into action. Similar to Jasper's (1988) findings, it was first anger and outrage and later sense of belonging, pride and hope that activated participants. These emotions by forming an emotional echo-chamber, motivated protestors for participating further and uniting despite their differences. We showed how the emotional echo-chamber helped connect protesters from various backgrounds of Turkish society, and once this diverse group shared a material space, they had the opportunity to interact and reflect on their common desires and criticisms and to help each other.

Anger and discomfort resulting from perceived injustices was the main reason why our participants took part in the protests. Emotions were not just single responses to external events (Wilkinson 2009) but were political and utilized within social protests. Once our participants were in the park, positive emotions like pride played an important role in their involvement, prolonging their presence in the protests. Pride in participating in the Gezi Park 
protests, the emphasis on Çapulcu identity, or hope for a better future all seemed to have contributed to their engagement. Gezi protests with its emphasis on solidarity and unity while making differences less important, enabled possible alliance and political mobilisation between ideologically very different groups. Emotional echo-chamber acted as a resource to fuel mobilisation efforts. Then, our participants' emotional experiences of activism and shared identity among a very diverse mass of activists, performing collective rituals like cleaning the park served as a social glue of the movement. This glue was the emotional chamber that brought very different groups together. The expressive use emotions like hope for future, in return enabled those emotions to spread to diverse communities and thousands of ideologically different groups to take part in the protests. The emotional-echo chamber is underpinned by work and activities during the Gezi Park protests. It is actively constructed and nourished through interaction in the park and online.

\section{Acknowledgments}

We would like to thank the Arts and Humanities Research Council (AHRC) for their support in funding the 'Aesthetics of Protest: Visual Culture and Communication in Turkey' (AH/N004779/1) project as well as Catherine Moriarty, Derya Güçdemir, and Emel Akcali for their help and support. We would like to thank the anonymous reviews we received on this paper. Finally, our gratitude to our interviewees who took the time to engage with our project, this research would not been possible without their input.

\section{Funding}

This work was supported by the Arts and Humanities Research Council, (AHRC) 'Aesthetics of Protest: Visual Culture and Communication in Turkey' (AH/N004779/1). 


\section{References}

Akcali, E. (2018) Do Popular Assemblies Contribute to Genuine Political Change? Lessons from the Park Forums in Istanbul. South European Society and Politics, 1-18.

Atak, K. (2013). "From Malls to Barricades: Reflections on the Social Origins of Gezi." Article presented at Rebellion and Protest from Maribor to Taksim: Social Movements in the Balkans, Graz, December 12-14.

Bernstein, Mary. (1997). "Celebration and Supression: The Strategic Uses of Identity by the Lesbain and Gay Movement.” American Journal of Sociology 103(3): 531-565.

Breuer, A., Landman T., and Farquhar, D. (2015). "Social media and protest mobilization: Evidence from the Tunisian revolution." Democratization 22, no. 4: 764-792.

Burul, Y., and Eslen-Ziya, H. (2018). Understanding 'New Turkey’Through Women's Eyes: Gender Politics in Turkish Daytime Talk Shows. Middle East Critique, 27(2), 179-192.

Castells, M. (2015). Networks of outrage and hope: Social movements in the Internet age. John Wiley \& Sons.

Cass, N., and Walker, G. (2009). Emotion and rationality: The characterisation and evaluation of opposition to renewable energy projects. Emotion, Space and Society, 2(1), $62-69$.

Cayli, B. (2017). Victims and protest in a social space: Revisiting the sociology of emotions. Emotion, Space and Society, 22, 61-70.

Collins, Randall. (2004). Interaction Ritual Chains. Princeton, NJ: Princeton University Press. 
Costa, J. M., Rotabi, R., Murnane, E. L., and Choudhury, T. (2015). It is not only about Grievances-Emotional Dynamics in Social Media during the Brazilian Protests. In Proceedings of the Ninth International AAAI Conference on Web and Social Media, 594597.

Damar, E. (2016). 'Radicalisation of Politics and Production of New Alternatives: Rethinking the Secular/Islamic Divide After the Gezi Park Protests in Turkey'. Journal of Contemporary European Studies, vol. 24, no. 2: 207.

Del Vicario, M., Vivaldo, G., Bessi, A., Zollo, F., Scala, A., Caldarelli G., and Quattrociocchi W. (2016). "Echo chambers: Emotional contagion and group polarization on Facebook." Scientific reports 6.

Erhart, I., (2014). United in protest: From 'Living and dying with our colours' to 'Let all the colours of the world unite'. The International Journal of the History of Sport, 31(14), 17241738.

Eslen-Ziya, H. and Erhart, I. (2015). “Towards Post-Heroic Leadership: A Case Study of Gezi's Collaborating Multiple Leaders. Special Issue: Leadership and Authority in a Crisesconstructing World”. Leadership. Vol. 11(4), 471-488.

Farro, A. L. and Demirhisar, G. D. (2014). “The Gezi Park Movement: A Turkish Experience of the Twenty-first-century Collective Movements.” Journal of Sociology 24 (1), 176-189.

Gamson, W. A. 1992. Talking politics. Cambridge Univ. Press

Garimella, K., De Francisci Morales, G., Gionis, A., and Mathioudakis, M. (2018). Political discourse on social media: Echo chambers, gatekeepers, and the price of bipartisanship. In Proceedings of the 2018 World Wide Web Conference (pp. 913-922). International World Wide Web Conferences Steering Committee. 
Goodwin, Jeff. (1997). "The Libidinal Constitution of a High-Risk Social Movement: Affectual Ties and Solidarity in the Huk Rebellion, 1946 to 1954." American Sociological Review 62(1), 53-69.

Goodwin, J. Jasper, J. M., and Polletta, F. (2000). “The Return of the Repressed: The Fall and Rise of Emotions in Social Movement Theory". Mobilization; an International Quarterly $5(1), 66-83$.

Goodwin, J. Jasper, J. M., and Polletta, F. (2001). "Why emotions matter" Passionate Politics: Emotions and social movements. Edt by J Goodwin, J. Jasper, M., and F. Polletta, Chicago and London: The University of Chicago Press.

Gould, Roger V. (1993). “Collective Action and Network Structure.” American Sociological Review 58(2), 182-196.

Gould, Deborah B. (2009). Moving Politics: Emotion and Act Up's Fight against AIDS. Chicago: University of Chicago Press.

Henderson, V.L., (2008). Is there hope for anger? The politics of spatializing and (re) producing an emotion. Emotion, Space and Society, 1(1), 28-37.

Jasper, J. M. (2011). Emotions and social movements: Twenty years of theory and research. Annual Review of Sociology 37, 285-303.

Jasper, J.M. (1998) The emotions of protest: affective and reactive emotions in and around social movements, Sociological Forum 13, 397-424.

Jasper, J. M. (1997). The Art of Moral Protest. Culture, Biography, and Creativity in Social Movements. Chicago: The University of Chicago Press.

Jasper, J. M., and Poulsen, J. D. (1995). "Recruiting strangers and friends: Moral shocks and social networks in animal rights and anti-nuclear protests." Social Problems 42, no. 4, 493512. 
Kim, H. (2002). Shame, Anger, and Love in Collective Action: Emotional consequences of Suicide Protest in South Korea, 1991. Mobilization: An International Journal, 7(2).

Keyman, E. F. (2014): The AK Party: Dominant Party, New Turkey and Polarization. In: Insight Turkey, Vol. 16, 19-31.

Koçan, G. and Öncü, A. (2014). “Anger in Search of Justice: Reflections on the Gezi Revolt in Turkey", Sociology of Islam, vol. 2, no. 3-4, 2014, 178-195

Korkut, U., and Eslen-Ziya, H. (2016). The Discursive Governance of Population Politics: The Evolution of a Pro-birth Regime in Turkey. Social Politics: International Studies in Gender, State \& Society, 23(4), 555-575.

Massumi, B. (2002): The Autonomy of Affect, in: Brian Massumi: Parables for the Virtual. Movement, Affect, Sensation, Durham \& London: Duke, 23-45.

McGarry, A., Jenzen, O., Eslen-Ziya, H., Erhart, I., and Korkut, U. (2019). Beyond the iconic protest images: the performance of 'everyday life' on social media during Gezi Park. Social Movement Studies, 284-304.

Navaro-Yashin, Y. (2013). "Breaking Memory, Spoiling Memorization: The Taksim Protests in Istanbul.” Cultural Anthropology. Houston. Accessed 3 July 2018.

Nepstad, S. E., and Smith, C. (2001). The social structure of moral outrage in recruitment to the US Central America peace movement. Passionate politics: Emotions and social movements, 158-74.

Van Troost, D., Van Stekelenburg, J., and Klandermans, B. (2013). Emotions of Protest. In N. Demertzis (Ed.), Emotions in Politics: The Affect Dimension in Political Tension. Palgrave Macmillan.

Van Ness, J., and Summers-Effler, E. (2018). Emotions in Social Movements. The Wiley Blackwell Companion to Social Movements, 411-428. 
Von Scheve, C. (2017). Collective emotions. The Wiley-Blackwell Encyclopedia of Social Theory, 1-3.

Wilkinson, E. (2009) The emotions least relevant to politics? Queering autonomous activism, Emotion, Space and Society 2(1), 36-43.

Woods, M., Anderson, J., Guilbert, S. and Watkin, S. (2012). "'The country (side) is angry’: Emotion and explanation in protest mobilization." Social \& Cultural Geography 13, no. 6: $567-585$.

Y1lmaz, S. H., and Y1lmaz, Y. G. (2015). A look at the Gezi park protests through the lens of media. International Journal of Social, Behavioral, Educational, Economic, Business and Industrial Engineering, 9, 2811-2817.

Yang, G. (2000). Achieving Emotions in Collective Action: Emotional Processes and Movement Mobilization in the 1989 Chinese Student Movement, 41(4), 593-614.

\section{Author Biography}

Hande Eslen-Ziya is an Associate Professor of Sociology at the University of Stavanger, Norway. She has a gender specialization from Central European University, in Budapest, Hungary. Her research Her research ranges over activism, protest and the use of digital technologies, men and masculinities as well as social politics.

Aidan McGarry is a Reader in International Politics at the Institute for Diplomacy and International Governance at Loughborough University, London. His research focuses on social movements, protest, political voice, and marginalized communities.

Olu Jenzen is Principal Lecturer at the University of Brighton, UK, and the Director of the Research Centre for Transforming Sexuality and Gender. Her research ranges over different themes in Media Studies and Critical Theory, with a particular interest in the aesthetics of protest, social media and LGBTQ activism and popular culture.

Itır Erhart is an Associate Professor in the Department of Media and Communication Systems, Istanbul Bilgi University. She is the author of the book 'What Am I?' and several articles on gender, sports, human rights, social movements and media.

Umut Korkut is Professor in International Politics at Glasgow School for Business and Society at Glasgow Caledonian University. Prof. Korkut has expertise in how political discourse makes audiences and has recently studied visual imagery and audience making. 